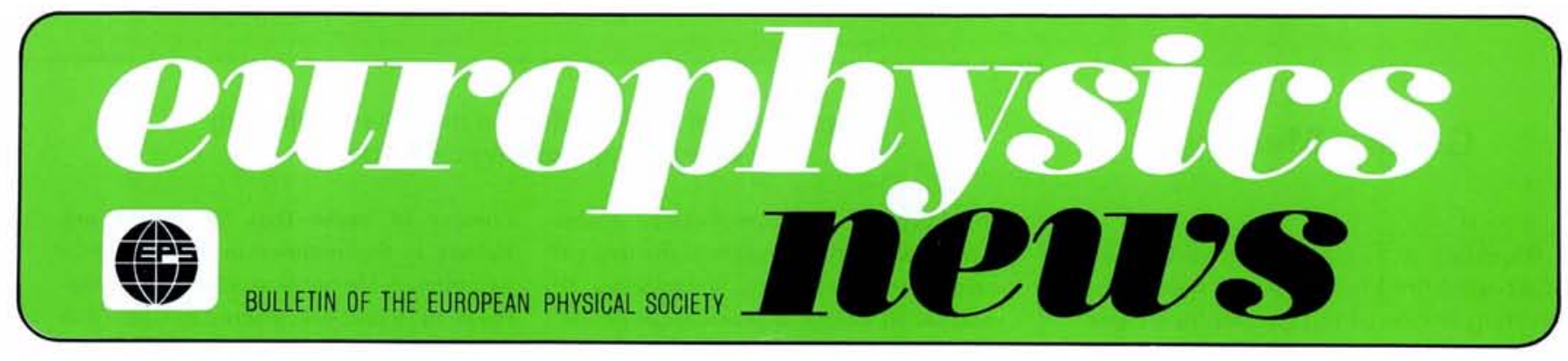

\title{
EPS in PRAGUE
}

Over 750 physicists from all corners of Europe, the United States and elsewhere assembled in Prague to attend the 6th General Conference of the European Physical Society, and incidentally appreciate the elegance of the city and the open welcome of its citizens. The largest contingent, as could be expected, was from Czechoslovakia where the opportunity was taken to introduce many young physicists to their colleagues from other countries and to hear some of the world's most distinguished physicists speak on their own particular topics.

\section{Council}

Before the Conference began, however, Council met for the second time this year to review the work of the Society, and was welcomed to Prague by Professor Ulehla, President of the Union of Czechoslovak Mathematicians and Physicists. Initially the meeting was preoccupied with a problem of principle created by the refusal of a visa to one of the delegates of the Individual Ordinary Members (F. Janouch). Council much regretted this incident and instructed the President to summarize to members at the General Meeting the background and conclusions (see panel). At the same time, it accepted the Executive Committee's unanimous view that the meeting was in no way invalidated as it was presently convened. This is not the first occasion when a visa has been refused to a participant at an EPS meeting and the Executive Committee agreed to make a study of the boundary conditions for the free movement of scientists and report to Council at its next meeting.

This was the first Council meeting at which delegates from the Associate Members were present and a warm welcome was given to them. Many references were made to the need for EPS to develop a better communication between these members and the Society and also to see how physicists working in industry could be better served by the Society. There was a tendency for industrial physicists to regard physical societies as being irrelevant to their occupation and many societies - not all - were feeling the need to correct this image.

Appreciation was expressed of the agreement of the Hewlett-Packard Company to continue to sponsor the prize in condensed matter physics for a further five years. This has been a most successful feature of the Society and G. Binnig who with $\mathrm{H}$. Rohrer was formally presented with the 1984 prize during the Conference, received something close to an ovation for his talk on scanning tunnelling microscopy. The Condensed Matter Division has been pressing for a similar prize to be created for materials research, the High Energy and Particle Physics Divisions is considering creating a prize, and there is some pressure for a range of divisional prizes and medals. This subject will come back into the agenda of the Executive Committee to see if the previous reluctance to extend the prize system should be modified.

A lively debate took place on the location of the next General Conference as three firm offers had been made of comparable attraction: from Geneva, Helsinki and Rotterdam. In essence, it was thought that Geneva already had its share of meetings and, whilst Rotterdam would no doubt attract a larger participation, the impact on Dutch physics would not be so significant as on Finnish physics. The cost of air travel from most western countries to Finland was the major deterrent but the pattern of previous Conferences suggested that one in North-East Europe would now be fair. Consequently the majority favoured Helsinki.

Council learned of the negotiations on the Europhysics Letters journal and the agreement signed by the three initiating societies (of France, Italy and the UK) with EPS, setting out the basic structure and contributions of each. On the scientific side a first priority was to appoint an Editor-in-Chief and then the succeeding levels of Co-editors, Advisory Editors and referees. Some anxiety was expressed that the Divisions would not be fully consulted, but the President gave assurances that as the scientific life of EPS was centred on the Divisions, their full participation was a sine qua non.

On the business side a provisional management committee had been formed and amongst its first tasks were the call for tenders for the publishing operations (see page 3 ) and the information to be sent to national societies setting out the detailed manner in which they will be able to participate. A number of societies had expressed an initial interest and have since confirmed that they will be investing in the venture.

$\begin{array}{ll}\text { Contents } & \\ \text { EPS in Prague } & \\ \quad \text { Council } & 1 \\ \text { General Meeting } & 2 \\ \quad \begin{array}{l}\text { Statement by the President } \\ \text { Trends in Physics }\end{array} & 2 \\ \quad \begin{array}{l}\text { Invitation to Tender } \\ \text { for Europhysics Letters }\end{array} & 3 \\ \begin{array}{l}\text { RF Driven Currents } \\ \text { in Fusion Devices }\end{array} \\ \begin{array}{l}\text { Characterisation of Biological } \\ \quad \text { Tissue by Ultrasound }\end{array} \\ \begin{array}{l}\text { New Members of EPS } \\ \text { New Collaborating Societies }\end{array} & 12 \\ \text { Divisional Elections } & 16 \\ & 16 \\ \end{array}$




\section{General Meeting}

Breaking with tradition, the General Meeting of the Members was held in the morning of one of the Conference days, which meant that people were more numerous and less tired. No new items had been proposed so the agenda was that published in the January issue of Europhysics News. In the reports of the President, Secretary and Treasurer a succint account was given of the state of the Society and its current projects (see page 1 and the June issue of EN). The meeting heard of the choice of Helsinki for the next rendez-vous and a firm offer from the Netherlands to stage the following event in 1990.

Main item on the agenda was the discussion of the future development of the Society which drew the following comments from the meeting:

- Some members would like to see the Society more involved in the social implications of physics and to play an active role on the question of disarmament, even trying to exert pressure on the many physicists who are engaged in weapons development. The EPS was accused of being much less concerned about the implications of nuclear weapons programmes than, e.g., the APS, but as the President stated: we are all aware of the problems, we published a statement setting out a consensus view of the Society (EN, July 1982) and we shall support the study groups being set up by ICSU. However, the Executive Committee was conscious of the need to confine itself to actions that could be effective rather than lose credibility by making empty gestures.

- The proposal was put forward that EPS should create many more Sections within the Divisions and move towards a position where many more specialist conferences would come under the EPS umbrella - a view countered by the comment that fractioning the existing Sections, some of which were quite small, could have a negative effect. There is no doubt here a chicken and egg situation: more members would encourage more Sections (or sub-Sections) to be set up, which would in turn no doubt attract more members.

- An appeal was made for EPS to throw its weight into the struggle to have better representation of women in physics, echoing a cri-de-cœur that had been made the previous day during the Sym-

\section{Statement of the President to the General Meeting of the European Physical Society}

The European Physical Society abides completely by the principle of the free circulation of physicists, irrespective of race, creed, colour or political conviction, and whenever any meeting is being arranged, appropriate assurances are sought on this matter.

In March 1982 a Statement of Principle was given to the EPS by the Czechoslovakian authorities. It read:

"Czechoslovak regulations do not exclude any scientist from taking part in international meetings held in Czechoslovakia for reasons of race, religion, political or philosophical conviction, ethnical origin, language or sex.

As far as citizenship is concerned, Czechoslovak authorities adhere to Czechoslovak law at the same time fully respecting the relevant resolution of the United Nations signed by Czechoslovakia."

According to Czechoslovak law there are two ways of relinquishing Czechoslovak nationality. One is release, whereby the person can return even after obtaining the nationality of another country. The second involves expatriation, in which case the person cannot return to Czechoslovakia (i.e. he is declared persona non grata).

I am informed that Professor Janouch first left Czechoslovakia on an emigrant's visa, but in the eyes of the Czechoslovak authorities he systematically conducted activities unfriendly towards Czechoslovakia, and, it is stated, he was warned a number of times that he should not behave in this manner. In 1975 he was expatriated. He became a Swedish national in 1979 and was elected to Council in 1983 one year after the decision was taken to hold the General Conference in Prague.

As physicists, we seek free movement to enable us to carry on our profession on the grounds that it is truly international and non-political. As an international federation of physical societies, it behoves us however, not to intervene in any way in the political affairs of any country. It is not for me as President of the EPS to comment on whether or not Professor Janouch "systematically conducted activities unfriendly towards Czechoslovakia".

Nevertheless, very considerable efforts were made to persuade the Czechoslovak authorities to reverse their decision, not only by those in Czechoslovakia responsible for the General Conference but also by the EPS Secretary Dr. Merz, by Professor Friedel as Chairman of the International Conference Board and by myself. I know too of other actions, for example by the President of the Danish Physical Society, by the President of the French Physical Society and a number of individuals.

We were not successful and I wish to emphasize Council's deepest regrets that the authorities could not have seen fit to grant a temporary visa to Professor Janouch, solely for a scientific visit to Czechoslovakia. posium on "Public Awareness of Physics". Whilst there are no women members of the Executive Committee at present, this has not always been the case and a number have been, and are prominent in Divisional activities.

- The Society was encouraged to strengthen its links with other regional physics societies (notably the APS) making the explicit recommendation that their Presidents be invited to future General Conferences. The President confirmed that the matter of cooperation was being actively discussed and more joint actions could be expected.

- Attention was drawn to the basic conflict between membership of a national society and membership of EPS, the contention being made that there was a tendency to join one or the other. This is not, however, born out by the membership figures as we have only 1154 a) members and some $35004 \mathrm{c}$ ) and d) members, but categories are being looked at and we may in the first instance be able to devise a special category for young physicists that would encourage them to be European as well as active locally.

On a final note of emphasising the dual characteristic of EPS - of being a federation of national societies and also a learned society in its own right - a formula that looks so awkward, yet has worked so well - the General Meeting closed and the Members went back to physics. 